\title{
Russian Colonialism in Central Asia: to Determine Time and Place
}

\section{Dmitry V. Vasilyev}

Moscow City University. Moscow, Russia. Email: dvvasiliev[at]mail.ru

\section{Abstract}

The article is a brief overview of Russian legislative practices in the Central Asian region.

Kazakh, Turkestan and Transcaspian lands are considered as a single region, as it was understood by the Russian imperial administration. The administration models implemented in it had a different nature and their own specifics. In this case, the time factor was of paramount importance. Russia had not yet formulated its agenda in relation to its southeastern periphery at the beginning of the $18^{\text {th }}$ century. At that time, St. Petersburg perceived the Kazakh steppe as the outer territory of the empire (colony) and consistently implemented methods of indirect and direct control towards it. The situation changed in the middle of the 19th century. The complication of the foreign policy situation in Europe provoked the intensification of Russia in Central Asia. Active advancement towards the Afghan border entailed the transformation of the Kazakh lands into the inner territory of the empire wanting administrative assimilation with the rest of the state. At the same time, a "non-colonial" view of the empire's national outskirts prevailed in the Russian capital. The trend towards the spread of general imperial administrative-political and socio-economic norms and approaches to Central Asian possessions has become the leitmotif of the state policy. The system of military-public administration became manifestation of this policy, introduced in the Kazakh steppe, Russian Turkestan and the Transcaspian province in the second half of the 19th century.

\section{Keywords}

Russian Empire; Colony; Colonialism; Central Asia; Kazakhs; Turkmens; Russian Turkestan; Transcaspian Region; Administration Policy; Military-Public Administration

This work is licensed under a Creative Commons "Attribution" 4.0 International License 


\section{Российский колониализм в Центральной Азии: определяя время и место}

\section{Васильев Дмитрий Валентинович}

Московский городской педагогический университет. Москва, Россия.

Email: dvvasiliev[at]mail.ru

\section{Аннотация}

Статья является кратким обзором российских законодательных практик в Центрально-Азиатском регионе. Казахские, туркестанские и закаспийские земли рассмотрены как единый регион в понимании российской имперской администрации. Реализовывавшиеся в нем административные модели имели различную природу и свою специфику. При этом важнейшее значение имеет фактор времени. В начале XVIII в., когда Россия еще не сформулировала свою повестку в отношении своих юго-восточных окраин, Петербург воспринимал Казахскую степь как внешнюю территорию империи (колонию) и реализовывал здесь последовательно приемы косвенного и прямого управления. В середине XIX в. ситуация меняется. Осложнение внешнеполитической обстановки в Европе спровоцировало активизацию России в Центральной Азии. Активное продвижение к афганской границе повлекло за собой превращение казахских земель во внутреннюю территорию империи, нуждавшуюся в административной ассимиляции с остальной территорией государства. Одновременно в российской столице возобладал «неколониальный» взгляд на национальные окраины империи. Тенденция к распространению на центральноазиатские владения общеимперских административно-политических и социально-экономических норм и подходов стала лейтмотивом государственной политики, реальным выражением которой явилась система военно-народного управления, реализованная в Казахской степи, Русском Туркестане и Закаспийской области во второй половине XIX в.

\section{Ключевые слова}

Российская империя; колония; колониализм; Центральная Азия; казахи; туркмены; Русский Туркестан; Закаспийская область; административная политика; военно-народное управление

Это произведение доступно по лицензии Creative Commons “Attribution” («Атрибуция») 4.0 Всемирная 


\section{Введение}

Ответ на вопрос о колониальном характере российской администрации в азиатском секторе ее владений следует искать не в отдельном локальном случае, а на базе большого региона, части которого в разное время входили в состав государства. Необходимо выделить регион, то есть территорию государства, видевшуюся из центра единым целым. Наиболее эффективным в этом отношении представляется региональный подход (Эмар, 1999; Каппелер, 2000, с. 21; Мацузато, 2004), позволяющий в рамках гетерогенного пространства империи рассмотреть государственную политику в отношении крупного геополитического пространства, воспринимавшегося имперским центром как единство.

В азиатском дискурсе Российской империи ее центральноазиатские окраины (Казахская степь, Туркестан, Закаспийский край) воспринимались как единое направление, к которому применимы некие универсальные административные подходы (Васильев, 2015; Васильев, 2018). И это дает нам основание рассматривать юго-восточную периферию государства как один регион (Сулейменов \& Моисеев, 1985; Почекаев, 2021). При этом названные выше три его составные части выступают в качестве субрегионов, каждый из которых имел определенное своеобразие в социально-экономической и административно-политической организации, что позволяет считать Казахскую степь, Русский Туркестан и Закаспийский край субрегионами Центрально-Азиатского региона.

Есть авторы, которые относят регион к сфере воображаемого пространства, ссылаясь на неопределенность самого понятия, концентрацию внимания на какой-то одной этнической группе и др. (Миллер, 2006, с. 14-33), выделяют в обособленный регион Среднюю Азию (Абашин, 2007, с. 19). Однако эти замечания применительно к Центральной Азии имперского периода представляются несущественными в том числе и потому, что российское правительство не видело здесь никаких национальностей, кроме русских (в широком контексте) и «туземцев» (коренных жителей), выделяя среди последних лишь оседлых и кочевников. Незначительную этнизацию риторики мы видим в отношении Закаспийского края, но и здесь положение туркмен фактически соответствовало положению кочевников соседнего Туркестана. Наконец, нет сомнения в том, что и в экономическом плане имперские владения на юго-востоке представляли собой единство, основанное на взаимодействии степного кочевого и оседлого хозяйства оазисов Мавераннахра.

История присутствия Российской империи в Центральной Азии знает примеры реализации различных моделей управления, устанавливавшихся в зависимости от тех задач, которые правительство намеревалось решить на конкретной территории (Васильев, 2019с). Из этих задач выбиралась главная, 
она и определяла не только облик административной модели, но и ее подведомственность. Среди органов центрального управления, реализовывавших властные полномочия в регионе в XVIII-XIX вв., последовательно были Министерство иностранных дел, Военное министерство, Министерство внутренних дел, даже Министерство государственных имуществ.

\section{Казахская степь}

История российского подданства казахов начинается в 1730-х гг., однако вплоть до конца столетия имперская власть воспринималась степняками как нечто постороннее, а то и бесполезное. Лишь их элита стремилась извлечь выгоду из новой политической ситуации. Пограничной же администрации оставалось утверждать свою легитимность любыми способами.

В глазах казахов Россия выступала как союзник. А потому они рассчитывали поставить ее экономические и политические ресурсы себе на службу. Свое взаимодействие с северным соседом рассчитывали выстроить как равноправное и свободное (Васильев, 2019а). На первых порах и сама империя не докучала своим новым подданным настолько, что они это подданство даже не замечали: не вмешивалась во внутренние дела казахов. Лишь изредка она организовывала карательные экспедиции с целью смирения особо буйных родовых групп, привлекала на свою сторону местную знать, всеми силами стремилась положить конец конфликтам казахов с проживавшими у границы башкирами и казаками. И в общем-то все это мало чем отличалось от повседневных практик самих кочевников. Используя различные инструменты мягкой силы, Петербург оказывал влияние на выборы ханов и утверждал их в этом достоинстве.

Российская столица пока еще считала Степь внешней имперской провинцией. Но уже к середине XVIII в. она поставила в повестку дня задачу укрепить здесь свое влияние. Поначалу решить вопрос попытались с минимальными политическими и финансовыми затратами, используя колониальный опыт других европейских монархий. Была избрана модель косвенного управления окраиной, которая, по мнению Петербурга, могла повысить управляемость казахскими землями. И это случилось, однако практика показала, что традиционные политические институты, призванные на службу империи, оказались не в состоянии эффективно обеспечить социальную стабильность в регионе. В условиях пробуксовки косвенной административной модели российской стороне пришлось перейти к неоднозначным мерам - к использованию межродовых противоречий казахов во избежание концентрации власти в одних руках, превращению ханов в своих апологетов, поддержанию потенциальных претендентов на ханское достоинство.

Играя на внутренних противоречиях в Казахской степи, российский МИД сам загнал себя в западню: нельзя делать ставку на ханскую власть, одновре- 
менно предпринимая меры, направленные на ее ликвидацию. С целью предотвращения антиправительственных выступлений власть поддерживала среди казахов родовое разобщение, сотрудничая с теми или иными родовыми группами. Однако такой подход не давал долгосрочных результатов - социальнополитическая ситуация балансировала на грани хаоса. Выдвижение на ханский престол лояльных империи султанов также оказалось неэффективным казахи зачастую отказывались нарушать традицию и поддерживать претендентов, власть которых не считали легитимной.

Приведение казахов к реальному подданству в Малой орде осуществлялось постепенно и исподволь через приласкание местной элиты, периодическое приведение казахов разного социального уровня к присяге, привлечение местного населения к русским пограничным населенным пунктам. Однако такие шаги зачастую вели к противоположному результату: провоцировали внутренние конфликты, снижали степень управляемости. Заметим, что более жесткие шаги в отношении населения Среднего жуза оказались на деле более эффективными.

Тем не менее следует признать, что в отношении своего внешнего региона Российская империя применяла к Казахской степи косвенное администрирование, в ограниченной степени вмешиваясь во внутренние дела и в местное управление, стремясь превратить казахских ханов в своих ставленников, демонстрируя свою власть лишь через периодические карательные экспедиции, не воспринимавшиеся тем не менее коренным населением как нечто экстраординарное и чужеродное.

Ближе к концу XVIII столетия начинается переход Казахской степи от косвенного управления к прямому. Власть ханов Малой орды, в результате имперской политики, направленной на разобщение казахской элиты и ее ослабление, стала в значительной степени номинальной. В этих условия российские власти решили оттянуть властные полномочия от ханов на вновь создаваемые административные структуры, существенно отличавшиеся от традиционных казахских институтов. Избегая прямого участия ханов в управлении Малой ордой, глава пограничной администрации О. А. Игельстром стремился создать оптимальные условия для трансляции в Степь имперской политики.

Создание новой системы управления в Малой орде существенно отдалили ее в административном отношении от Средней, заложив тем самым фундамент для формирования различных моделей управления регионом, но продемонстрировали наметившуюся тенденцию на использование в Казахской степи общеимперских принципов администрирования. Можно сказать, что с этого времени регион вступил на путь адаптации к общероссийским политическим реалиям. С другой стороны, в преобразованиях О. Игельстрома можно усмотреть попытку сохранить в Казахской степи косвенное администрирование, отсрочить переход к более затратному прямому варианту. 
Шагом на пути внедрения в Казахской степи системы прямого имперского управления стала реформа М. М. Сперанского в Средней орде. По Уставу о сибирских киргизах 1822 г. (Полное собрание законов Российской империи, 1830, с. 417-433) в Степи были введены должности избранных старшин в аулах, султанов в волостях и старших султанов в округах. Окружным приказам (с участием российских и местных заседателей) придавалась полицейская и судебная власть. Административные функции выполняла канцелярия, которая вела делопроизводство на русском и татарском языках.

Должностные лица первичной администрации были приравнены к чинам Российской империи. Старший султан (теперь - земский чиновник) управлял казахами от имени российского правительства; за порядок и благосостояние населения отвечал окружной приказ как присутственное место, которому подчинялись волостные. Вновь созданные приказы соответствовали земским судам внутренней России. Аульные старшины фактически приравнивались к сельским старостам.

Утверждение Устава о сибирских киргизах и Устава об управлении инородцев (Полное собрание законов Российской империи, 1830, с. 394-417) в 1822 г. фактически вело к утверждению в степи прямого управления, что в конкретной ситуации означало постепенное включение новых территорий в ординарную жизнь государства. Установка на сближение новой системы управления с общероссийской свидетельствует о тенденции к административной ассимиляции региона.

Более чем на десятилетие растянулись административные преобразования в Малой казахской орде. В 1844 г. было утверждено Положение об управлении оренбургскими киргизами (Полное собрание законов Российской империи, 1845, сс. 392-401).

Согласно этому закону, местное (частное) управление в Казахской степи составляли представители местного населения: султаны-правители, дистаночные начальники и начальники аулов. Главным административным органом для Малой орды становилась Оренбургская пограничная комиссия. Для обеспечения защиты интересов прилинейных казахов вводились должности попечителей из российских чиновников.

Председатель Оренбургской пограничной комиссии управлял этим коллегиальным учреждением на основании Общих губернских учреждений, а само оно исполняло обязанности губернского правления, казенной палаты, гражданского и уголовного суда, а также палаты государственных имуществ.

Таким образом, проведение в жизнь реформ 1822-1824 гг. и более позднего времени, связанных с изменением управленческих тактик в отношении казахов западносибирского и особенно оренбургского ведомств, означало, что в Казахской степи внедрялось прямое имперское управление. Благодаря реформам были законодательно оформлены основные принципы имперского 
управления Степью и заложены принципиальные различия трех административных моделей для казахов.

Статус Казахской степи в Российской империи не был некоей раз и навсегда установленной константой. Анализ обширной источниковой базы дает основания утверждать, что на протяжении XVIII-XIX вв. он прогрессировал в контексте субъектности российской государственности от фактического союза второй четверти XVIII в. через вассалитет второй половины того же столетия к реальному подданству XIX в.

Значимым этапом на пути сближения Степи с остальной территорией империи стало Временное Положение об управлении в Уральской, Тургайской, Акмолинской и Семипалатинской областях 1868 г. (Материалы по истории политического строя Казахстана, 1960, сс. 323-340), которое, унифицируя местную администрацию, вводило в Степи общегосударственные учреждения и институты. С этого момента мы уже не можем говорить о каком-либо варианте колониального администрирования. В Казахской степи начался бесповоротный процесс превращения ее в ординарную часть государства, который зачастую сопровождался непониманием со стороны коренного населения (Васильев, 2019b).

Распространяя на край значительную часть общероссийских установлений, предоставляя казахам права сельских обывателей империи, причем даже с серьезными льготами, правительство на деле подтверждало неуклонность своего курса на неразрывное сращивание Казахской степи с внутренними областями России в единое и неделимое государство.

\section{Русский Туркестан}

Продвижение России на юг в середине XIX в. побудительно было связано с необходимостью обеспечения безопасности казахских владений, которые империя уже стала воспринимать как свои безусловные (не внешние) владения. Кроме того, потребность усиления военного присутствия в регионе провоцировалась периодическими межказахскими и антиправительственными выступлениями в степи.

О смыслах и целях российского проникновения в Туркестан писали Н. П. Глиноецкий, М. И. Венюков, М. А. Терентьев, А. К. Гейнс, Л. Ф. Костенко и др. (Венюков, 1872; Гейнс, 1897; Глиноецкий, 1860; Костенко, 1871; Терентьев, 1875). В качестве главного стимула были названы близость территории к российским границам, геополитическое положение региона. С точки зрения А. К. Гейнса, М. И. Венюкова, Л. Ф. Костенко военное продвижение обеспечивало безопасность границ, способствовало умиротворению Степи, поэтому являлось необходимым. При этом полагали, что империя выступает как транслятор европейской цивилизации на окраинах, тем самым защищает цивилизованный мир и облагораживает варварскую среду. Эта концепция «самосохра- 
нения России» трансформировалась во второй половине XIX в. в теорию «естественных границ», которая подразумевала фиксирование границы империи на естественных рубежах (горы, реки, мощные и стабильные государства) и необходимость ее защиты с помощью новых завоеваний, а также военного укрепления своих позиций (Абаза, 1902; Торнау, 1914; Юдин, 1912).

Из завоеванных с 1854 г. земель в начале 1865 г. была образована Туркестанская область в составе Оренбургского генерал-губернаторства с центром в Чимкенте. А уже 17 июня Черняеву удалось исполнить свою мечту. Войсками под его командованием Ташкент был занят.

Примечательно, что главный начальник Оренбургского края уже в это время (в начале 1867 г.) выдвинул тезис, который станет основой имперской политики до конца существования Русского Туркестана: этот край необходимо сделать «частью империи, а не отделять в виде особой удаленной колонии в качестве особого генерал-губернаторства» (Российский государственный исторический архив, 1867а, л. 6 об.).

Член Степной комиссии Ф. К. Гирс обратил внимание на разные механизмы вхождения в состав России двух регионов - Казахской степи и Туркестанской области. Если Степь стала частью Российской империи добровольно, то Туркестан был завоеван. Отсюда происходили и исходные различия в административных принципах для степных и оседлых жителей этой части российских владений, которые

«...не изменились и в настоящее время. Поэтому нет основания нарушать административными мерами, не вызываемыми ходом дела, установившуюся связь известных местностей между собой» (Российский государственный исторический архив, 1867b, лл. 4-6об., 11об.-12).

Так в Туркестанском крае начала складываться особая административная система (военно-народное управление), отличная от степной. Положение об управлении Семиреченской и Сырдарьинской областей приближало административные органы в Туркестане к соответствующим в иных частях империи и предоставляло местное управление выборным лицам из среды коренного населения, за исключением дел политического характера (Кауфман, 1885, с. 83). Документ фактически провозглашал в качестве перспективы введение региона в общегражданскую жизнь Российской империи.

12 июня 1886 г. законодательное утверждение получило новое Положение об управлении Туркестанского края. Законодательный акт устанавливал более глубокую регламентацию прав, обязанностей и полномочий имперской администрации в крае; на уездном уровне вводилось окончательное разделение власти, военной и гражданской. Местная администрация была четко структурирована, а также унифицирована в отношении оседлого и кочевого населения. Документ определял организацию отраслевых учреждений центрального подчинения; при этом сильная власть генерал-губернатора сохранялась, при нем создавался совет. Закон приближал оседлое коренное население 
по своему положению к жителям центральных районов России и создавал условиях как для развития оседлости в крае, так и для русской колонизации. Все это указывает, по нашему мнению, на стремление интегрировать Туркестан в состав империи, построить организацию управления и быта населения края на основе порядков, установленных для других областей Российской империи.

\section{Закаспийский край}

В постановлениях верховной власти рубежа 1860-1870-х гг. определялись две цели занятия Красноводска на восточном берегу Каспийского моря развитие транзитной торговли с ханствами и умиротворение Хивы. Именно в таком порядке, который нарушал уже успешно испытанную в соседнем Туркестане систему, когда гражданское устройство и торговые интересы шли за решением военных задач. То же самое в полной мере относится и к Казахской степи, относительно мирно вошедшей в состав империи. Не исключено, что порядок расставленных для восточного побережья Каспийского моря приоритетов был определен не столько неосведомленностью в региональных условиях, сколько внешнеполитическими обстоятельствами.

22 августа 1869 г., когда состоялось высочайшее повеление о занятии пункта у Красноводского залива, Российская империя приступила к активным действиям на восточном берегу Каспийского моря.

На новых имперских территориях гражданское население фактически отсутствовало. По этой причине на правительственном уровне было принято решение воздержаться от учреждения особого административного округа. Однако следовало позаботиться о безопасности и создать условия, необходимые для ежедневного бытия российских военных, торговцев, российских и иностранных, будущих поселенцев. Этот административный функционал был возложен на начальника военного отряда. Отвечать за безопасность, порядок должно было иное должностное лицо - начальник морской станции на острове Ашур-Аде. Задача способствовать торговому развитию края была возложена на специального агента Министерства финансов и зафиксирована в его инструкции. Собственно, административное освоение региона началось в 1870 г., с момента принятия решения о направлении специального коммерческого агента в Красноводск. В начале февраля 1870 г. император утвердил соответствующее решение Комитета по делам, касающимся Каспийского моря (Присоединение Туркмении к России, 1960, с. 38-43).

Предложенный вариант региональной политической системы отличался своеобразным троевластием. Административными полномочиями наделялись три должностных лица - военный и морской начальники, а также агент Министерства финансов. Одновременно прорабатывалась идея организации 
купеческого самоуправления. Однако распространять российское управление на местное население (туркмен) власти не планировали (Васильев, 2020).

Российское правительство при занятии пункта на восточном берегу Каспийского моря было нацелено на открытие нового торгового пути в Среднюю Азию и создание необходимых условий торговым людям, включая обеспечение их безопасности. С учетом этой цели была дана особая инструкция военному начальнику края. Ему запрещалось занимать новые пункты Туркменской степи, также направлять войска для сопровождения караванов. Небольшие военные команды можно было направлять в окружные земли только для удовлетворения хозяйственных потребностей в топливе, фураже.

При любых действиях, передвижениях в крае следовало помнить о кочевом населении: с туркменами необходимо было сохранять мирные отношения, неспровоцированные действия против них считались незаконными. Действия против Хивы также объявлялись вне закона. Краевой военной администрации запрещалось взимать подати, сборы с туркменского населения, распространять на них нормы российского управления. Напротив, следовало вызвать у них доверительное, дружелюбное отношение, заинтересовать их торговыми делами, а также содействовать транзитной торговле с туркменами и хивинцами.

Для стимулирования развития торговли в крае представителю Министерства финансов надлежало содействовать установлению контактов местных жителей, купцов, приказчиков - подданных Российской империи и иностранных торговцев из азиатских государств. Ему следовало регулировать сделки, отслеживая точность выполнения их условий, а также принимать меры по пресечению обманов (Российский государственный исторический архив, 1870, л. 164).

Становление особой региональной политической системы в Закаспийском крае шло постепенно, при этом с российской стороны существовали далеко идущие планы. Занятием Красноводска решалась и другая цель - снять хивинскую угрозу. Для этого был необходим военный отряд. При организации региональной политической системы в крае правительство не разделяло эти две цели, торговую и военную, по значимости. Заметим, реализация любых гражданских интересов в то время была нереальна без масштабного военного обеспечения. Однако первоначально следовало решить военные задачи, тем самым создать в регионе оптимальные условия для промышленности, торговли. На это не обратили внимания, и, как следствие, сотрудничество администрации, военной и гражданской, в крае, не складывалось в течение длительного периода.

В 1874 г. было утверждено Временное Положение о военном управлении в Закаспийском крае (Россия и Туркмения в XIX веке, 1946, с. 91-99), оставлявшее субрегион в полной зависимости от кавказской администрации. 
Документ этот имел оперативный характер и даже стилистически отличался от действовавшего законодательства для соседних регионов. Его нормы в отношении коренного населения, и в первую очередь для туркмен, носили отчасти ретроградный характер, сохранявший даже родовые пережитки, относительно успешно изживавшиеся, например, в соседнем Туркестанском генерал-губернаторстве. Российская администрация в этом законе была призвана исполнять в основном попечительные функции, а местные туркмены лишь приготовлялись к распространению на них норм, принятых в отношении кочевавших по соседству казахов, относительно давно уже принявших подданство Российской империи.

В мае 1881 г. на месте бывшего военного отдела была образована Закаспийская область, а 10 июня 1882 г. высочайшее утверждение получило Временное Положение об управлении Закаспийской областью и войсками, в оной расположенными (Систематический сборник приказов по военному ведомству и циркуляров Главного штаба за время с 1 января 1869 года по 1 октября 1882 года, 1883, сс. 212-216). Новый закон фиксировал изменившийся административно-территориальный состав области (присоединение новых земель и образование трех уездов), регламентировал функции областного штаба и уездных управлений. Однако в новом законе опять не были прописаны функции гражданского отделения областного штаба, а функционал новых уездных начальников фактически дословно повторял функционал бывших приставов в отношении коренного населения.

6 февраля 1890 г. законодательное утверждение получило Временное Положение об управлении Закаспийской области (Свод законов Российской империи, 1892, с. 1-7 (6-я паг.)), фиксировавшее на этот раз прямое ее подчинение Военному министерству. Оно в основном повторяло уже известные обязанности начальника области. Механизм осуществления начальником области функций по гражданскому управлению области не был прописан и в новом законе. То же касается и обязанностей уездного начальника, которые ничуть не изменились с 1874 г.

\section{Выводы}

Итак, продвижение Российской империи в Центральную Азию шло по разным направлениям, было обусловлено различными целями и имело различный характер. А они, в свою очередь, определяли уровень и темп административной ассимиляции того или иного субрегиона. Казахская степь с 1730-х гг. начала свою историю добровольного вхождения в состав Российской империи, мотивированного как внешне- и внутриполитическими интересами части казахской элиты, так и желанием Петербурга открыть для себя врата Востока. И здесь долгое время сохранялись традиционные политические и судебные институты, отказ от которых фактически произошел 
столетие спустя в связи с изменением отношения государства к юго восточным территориям и его намерением окончательно ассимилировать эти земли в составе единого государства.

Несмотря на наличие заморских территорий, Российская империя существовала как континентальная империя, с XVI столетия избравшая путь интеграции национальных регионов в состав своего единого гетерогенного пространства. Она не просто имела опыт административно-территориальной и социально-экономической ассимиляции; этот опыт в зоне наиболее активного роста империи неизменно приносил успех, как бы тяжело он ни давался. Поэтому и Казахская степь недолго оставалась на положении внешней периферии государства, призванной стать буфером у южных рубежей государства. Колониальный статус казахских владений, весьма выгодный в политическом и экономическом отношениях, оказался неприемлемым не только потому, что косвенная администрация не обеспечивала безопасность в степи, а прямая оказалась непонятной коренному населению и чрезвычайно неэффективной. В период реализации тенденции к административной унификации вширь, России было проще распространить сюда общеимперские управленческие практики. Не стоит снимать со счетов и масштабные буржуазные преобразования, постепенно затрагивавшие не только новые сферы жизни империи, но и новые территории. Поэтому Россия не могла оставить на особом положении свою юго-восточную периферию. Она вступила на долгий путь последовательной трансформации местных административных и социальных институтов в русле общеимперских установок, который должен был завершиться превращением степных областей в рядовые губернии единого государства.

Южные казахские земли и оазисы Туркестана присоединялись к России позднее и военным путем. На этот раз речь шла не об интересах торговли, а об обеспечении эффективной защиты собственных подданных и реализации геополитических интересов. К 1860-м гг. Россия уже сменила колониальный дискурс на идею буржуазной унификации как средства стабильного развития империи. Покоренные земли в административном отношении попали в условия военно-народного управления. Нацеленное на закрепление в регионе общеимперских практик, оно на полстолетия определило жизнь Русского Туркестана.

Своеобразная ситуация сложилась в Закаспийском крае. Исходя из непростой внешнеполитической обстановки и не желая, по опыту соседних территорий, расходовать значительные ресурсы, Россия начала здесь исключительно с протекционизма торговым интересам. Но вскоре перешла к уже испытанному и простому военно-народному управлению, причем в его наиболее одиозном проявлении. Гораздо проще оказалось уложить новый субрегион в прокрустово ложе военно-административных порядков, чем создавать нечто новое и выстраивать гармоничные отношения с местными жителями. Упрощение указанных порядков, ради экономии, превратилось 
в длительное сохранение народных обычаев при почти полной бесконтрольности областного начальства.

\section{Благодарности}

Исследование выполнено за счет гранта Российского научного фонда (проект №19-18-00162), реализуемого в Институте языков и культур имени Льва Толстого.

\section{Список литературы}

Абаза, К. (1902). Завоевание Туркестана: Рассказы из военной истории, очерки природы, быта и нравов туземщев в общедоступном изложении. Типография М. М. Стасюлевича.

Абашин, С. Н. (2007). Национализмы в Средней Азии. Свободная мысль, 7, 138-150.

Васильев, Д. В. (2015). Форпост илперии. Административная политика в Центральной Азии. Середина XIX века. ИБП.

Васильев, Д. В. (2018). Бремя империи. Административная политика России в Центральной Азии. Вторая половина XIX в. Политическая энциклопедия.

Васильев, Д. В. (2019а). Аберрация взаимодействия: Ложно понятые смыслы российско-казахских реалий XVIII в. История, 1, 7. https://doi.org/10.18254/S0002320-1-1

Васильев, Д. В. (2019b). Проведение административной реформы 1868 года в Казахской степи: Судьба одной семьи. Новый исторический вестник, 1, 61-76. https://doi.org/10.24411/2072-9286-2019-00004

Васильев, Д. В. (2019с). Российская империя в Центральной Азии: Опыт управления окраиной. История, 8, 14. https://doi.org/10.18254/S207987840006019-9

Васильев, Д. В. (2020). Дуализм российской администрации на восточном берегу Каспийского моря. Вестник Санкт-Петербураского университета. История, 65(1), 85-107. https://doi.org/10.21638/11701/spbu02.2020.105

Венюков, М. (1872). Общий обзор постепенного расширения русских пределов в Азии и способов обороны их. Военный сборник, 83(2), 195-228.

Гейнс, А. К. (1897). Собрание литературных трудов (Т. 1). Типография М. М. Стасюлевича.

Глиноецкий, Н. П. (1860). Причины, побуждающие русское правительство время от времени действовать наступательно на границе со Средней Азией. Взятие Токмака и Пишпека. Военный сборник, 11, 175-184.

Каппелер, А. (2000). «Россия - многонациональная империи»: Некоторые размышления восемь лет спустя после публикации книги. Аb Imperio, 1, 15-32. https://doi.org/10.1353/imp.2000.0003

Кауфман, К. П. (1885). Проект всеподданнейшего отчета генерал-адъютанта К. П. Фон-Кауфмана по гражданскому управлению и устройству в областях Туркестанского генералгубернаторства. Военно-ученый комитет Главного штаба.

Костенко, Л. Ф. (1871). Средняя Азия и водворение в ней русской гражданственности. А. Ф. Базунов. 
Материалы по истории политического строя Казахстана (Т. 1). (1960). Издательство Академии наук КазССР.

Мацузато, К. (2004). Генерал-губернаторства в Российской империи: От этнического к пространственному подходу. В Новая илперская история постсоветского пространства (сс. 427-458). Центр исследования национализма и империи.

Миллер, А. (2006). Илперия Романовых и нащионализм. Новое литературное обозрение.

Полное собрание законов Российской илперии (Т. 38). (1830). Тип. 2-го Отделения Собственного его императорского величества канцелярии.

Полное собрание законов Российской илперии (Тт. 19, отд. 1). (1845). Тип. 2-го Отделения Собственного его императорского величества канцелярии.

Почекаев, Р. Ю. (2021). Нетипичные источники судебных решений правителей государств Центральной Азии XVI-XIX вв. Письменные памятники Востока, 18(1), 62-73.

Присоединение Турклении к России. (1960). Издательство Академии наук Туркменской ССР.

Российский государственный исторический архив. (1867a). Ф. 400. Оп. 1. Д. 4786.

Российский государственный исторический архив. (1867b). Ф. 400. Оп. 1. Д. 4787.

Российский государственный исторический архив. (1870). Ф. 846. Оп. 16. Д. 6819.

Россия и Туркмения в XIX веке (Т. 1). (1946). Туркменгосиздат.

Свод законов Российской илперии (Т. 2). (1892). Тип. 2-го Отделения Собств. его императорского величества канцелярии.

Систематический сборник приказов по военному ведомству и циркуляров Главного штаба за время с 1 января 1869 года по 1 октября 1882 года. (1883). Типо-лит. Фреймана.

Сулейменов, Р. Б., \& Моисеев, В. А. (1985). Ч. Ч. Валиханов как исследователь Центральной Азии. Народы Азии и Африки, 6, 62-70.

Терентьев, М. А. (1875). Россия и Англия в Средней Азии. Тип. П. П. Меркульева.

Торнау, Н. Н. (1914). К истории приобретений России в Азии. Сенатская типография.

Эмар, М. (1999). Категории «Центр» и «периферия» в историографии XX в. В Европейский опыт и преподавание истории в постсоветской России (сс. 68-69). Институт всеобщей истории $\mathrm{PAH}$.

Юдин, М. Л. (1912). Взятие Ак-Мечети в 1853 году как начало завоевания Кокандского ханства. Издательство В. Балашева.

\section{References}

Abashin, S. N. (2007). Nationalisms in Central Asia. Open-mindedness, 7, 138-150. (In Russian).

Abaza, K. (1902). The Conquest of Turkestan: Accounts of Military History, Essays on the Nature, Life and Manners of the Natives, in a Generally Accessible Compendium. M. M. Stasiulewicz printing house. (In Russian).

Code of Laws of the Russian Empire (Vol. 2). (1892). Printing office of the 2nd Department of His Imperial Majesty's Chancellery. (In Russian). 
Complete Collection of Laws of the Russian Empire (Vol. 19, c. 1). (1845). Printing office of the 2nd Department of His Imperial Majesty's Chancellery. (In Russian).

Complete Collection of Laws of the Russian Empire (Vol. 38). (1830). Printing office of the 2nd Department of His Imperial Majesty's Chancellery. (In Russian).

Emar, M. (1999). Categories of 'centre' and 'periphery' in 20th century historiography. In The European experience and history teaching in post-Soviet Russia (pp. 68-69). Institute of General History, Russian Academy of Sciences. (In Russian).

Gaines, A. K. (1897). A collection of literary works (Vol. 1). M. M. Stasiulewicz printing house. (In Russian).

Glinoyetsky, N. P. (1860). The reasons prompting the Russian government to act offensively from time to time on the border with Central Asia. The capture of Tokmak and Pishpek. Military collection, 11, 175-184. (In Russian).

Kappeler, A. (2000). "Russia - A Multinational Empire": Some Reflections Eight Years After the Book's Publication. Ab Imperio, 1, 15-32. https://doi.org/10.1353/imp.2000.0003 (In Russian).

Kaufman, K. P. (1885). Draft report of Adjutant General K.P. von Kaufman on civil administration and arrangement in the regions of Turkestan Governorate General. Military Scientific Committee of the General Staff. (In Russian).

Kostenko, L. F. (1871). Central Asia and the introduction of Russian citizenship. A. F. Bazunov. (In Russian).

Materials on the history of Kazakhstan's political system (Vol. 1). (1960). The publishing house of the Academy of Sciences of the Kazakh SSR. (In Russian).

Matsuzato, K. (2004). Governorates-General in the Russian Empire: From Ethnic to Spatial Approach. In A new imperial history of the post-Soviet space (pp. 427-458). Centre for the Study of Nationalism and Empire. (In Russian).

Miller, A. (2006). The Romanov Empire and nationalism. New Literary Review. (In Russian).

Pochekaev, R. Yu. (2021). Atypical sources of judicial decisions by Central Asian rulers in the 16th-19th centuries. Written monuments from the East, 18(1), 62-73. (In Russian).

Russia and Turkmenistan in the 19th century (Vol. 1). (1946). Turkmengosizdat. (In Russian).

Russian State Historical Archive. (1867a). F. 400. In. 1. C. 4786. (In Russian).

Russian State Historical Archive. (1867b). F. 400. In. 1. C. 4787. (In Russian).

Russian State Historical Archive. (1870). F. 846. In. 16. C. 6819. (In Russian).

Suleimenov, R. B., \& Moiseev, V. A. (1985). Ch. Ch. Valikhanov as a researcher of Central Asia. People of Asia and Africa, 6, 62-70. (In Russian).

Systematic collection of military orders and circulars of the General Staff from 1 January 1869 to 1 October 1882. (1883). Freiman lithography. (In Russian).

Terentiev, M. A. (1875). Russia and England in Central Asia. Printing house of P. P. Merkuliev. (In Russian).

Tornau, N. N. (1914). Towards a history of Russian acquisitions in Asia. Senate printing house. (In Russian).

Turkmenistan's accession to Russia. (1960). Publishing house of the Academy of Sciences of the Turkmen SSR. (In Russian). 
Vasiliev, D. V. (2015). An outpost of empire. Administrative policy in Central Asia. Mid-19th century. ИБП. (In Russian).

Vasiliev, D. V. (2018). Burden of Empire. Russian administrative policy in Central Asia. The second half of the 19th century. Political Encyclopaedia. (In Russian).

Vasiliev, D. V. (2019a). The aberration of interaction: Falsely understood meanings of Russian-Kazakh realities in the 18th century. History, 1, 7. https://doi.org/10.18254/S0002320-1-1 (In Russian).

Vasiliev, D. V. (2019b). The Administrative Reform of 1868 in the Kazakh Steppe: One Family's Fate. A new history bulletin, 1, 61-76. https://doi.org/10.24411/2072-9286-2019-00004 (In Russian).

Vasiliev, D. V. (2019c). The Russian Empire in Central Asia: The Experience of Managing a Suburb. History, 8, 14. https://doi.org/10.18254/S207987840006019-9 (In Russian).

Vasiliev, D. V. (2020). The dualism of Russian administration on the eastern shore of the Caspian Sea. Herald of St Petersburg University. History, 65(1), 85-107. https://doi.org/10.21638/11701/spbu02.2020.105 (In Russian).

Venyukov, M. (1872). A General Overview of the Gradual Expansion of the Russian Frontiers in Asia and the Means of Defending Them. Military collection, 83(2), 195-228. (In Russian).

Yudin, M. L. (1912). The capture of Ak-Mosque in 1853 as the beginning of the conquest of the Kokand Khanate. Published by V. Balashev. (In Russian). 